\title{
Os múltiplos olhares da História
}

\author{
The multiple glances of History
}

\begin{abstract}
A capa deste número da Esboços é uma composição elaborada a partir da fotomontagem Bouquet of Eyes (1930), de Hannah Hoch (1889-1978). Considerada precursora da fotomontagem, Hoch também foi uma intelectual feminista importante a partir da República de Weimar, quando sua arte passou a abordar como as dicotomias são estruturadas socialmente e qual o lugar dos discursos políticos nestas construções. Os temas e problemas da artista dadaísta e intelectual alemã, elaborados há quase 90 anos, permanecem perturbadoramente atuais. Se há pouco, muitos intelectuais das humanidades expressavam suas preocupações acerca da polarização política no país, da superficialidade em perspectivas conservadoras e alinhadas a movimentos e políticos de Direita, hoje as avaliações relativas à um recrudescimento destas questões estão bem mais adensadas. Os múltiplos olhares lançados por historiadores e historiadoras sobre os retrocessos, divergências, desafios e soluções para os problemas nacionais nas últimas décadas vão ao encontro de como Hoch buscava uma perspectiva crítica capaz de encorajar a libertação e ação das mulheres em um momento de grave crise política e social. Os trabalhos neste número representam bem a vitalidade, diversidade e vigor crítico das humanidades em um momento delicado, de ataque aos Direitos Humanos, desprezo por pessoas em situação de vulnerabilidade social e de tentativas sistemáticas de interdição das lutas contra privilégios de grupos dominantes. No artigo Da segurança à cobiça: um breve relato da transição dos argumentos abolicionistas nas propostas legislativas no Parlamento, que abre essa edição, Guilherme Del Negro discute como os debates legislativos no parlamento brasileiro sobre a proibição do tráfico e a abolição da escravidão desmontam a imagem de uma apatia institucionalizada ou de um comprometimento dissimulado com a causa abolicionista no cenário internacional. Em seguida, Thiago Tremonte de Lemos com o trabalho Modiano historiador: a ambiguidade francesa durante a ocupação alemã compreendida na obra Ronda da noite, aborda a obra do escritor francês Patrick Modiano, para refletir sobre os limites e os encontros entre a história e a ficção literária nas narrativas da ocupação alemã

(c) EY Direito autoral e licença de uso: Este artigo está licenciado sob uma Licença Creative Commons. Com essa licença você pode compartilhar, adaptar, para qualquer fim, desde que atribua a autoria da obra, forneça um link para a licença, e indicar se foram feitas alterações.
\end{abstract}


na França, durante a Segunda Guerra Mundial. Arnaldo Lucas Pires Junior, no artigo $A$ invenção da diferença: a animalização como distinção do "eu" e do "outro" no imaginário ocidental nos séculos XVIII e XIX, elabora uma discussão teórica sobre um dos expedientes mais correntes de diferenciação entre os homens, a animalização do "outro", por meio da análise de relatos de viagem e de obras de história natural nos sécs. XVIII e XIX. Deivid Aparecido Costruba, no trabalho Entre o real e o ficcional: uma análise do romance A Casa Verde (1898-1899), discute os limites entre o real e o ficcional no romance A Casa Verde, escrito pelo casal Filinto de Almeida (1857-1945) e Julia Lopes de Almeida (1862-1934), publicado em folhetim no Jornal do Comercio, entre 1898 e 1899. Como demonstra o autor, o casal procura não só examinar a imagem da mulher na sociedade daquele momento, como também o de estruturar o texto em torno de aspectos da anglofilia. A Guerra dos Farrapos é o tema trabalhado no artigo Guerra dos Farrapos (1835-1845): entre o fato histórico e suas apropriações, de Ânderson Marcelo Schmitt, a partir de uma documentação primária disponibilizada pelo Arquivo Histórico do Rio Grande do Sul, bem como dos exemplares do periódico oficial farroupilha. Em Armado com sua fé e sua medicina: visões da África e do africano a partir do diário de Albert Schweitzer, Naiara Krachenski Stadler busca compreender de que formas o discurso médico foi um elemento estruturante na produção e reprodução sobre estereótipos da África e do africano no contexto do imperialismo europeu. Para tanto, a autora se baseia nas memórias do médico alemão Albert Schweitzer sobre seu trabalho entre os anos de $1913 \mathrm{e}$ 1916 na África Equatorial Francesa. Priscila Bermudes Peixoto e Leonardo Dallacqua de Carvalho analisam as abordagens sobre a sífilis encontradas na Revista de Medicina no artigo "Memento lues, delenda lues!" A profilaxia e o tratamento da sifilis na Revista de Medicina nos anos 1920. Para o autor e a autora, a sífilis era entendida no contexto dos anos 1920 como um fator de degeneração, mencionada como consequência de um comportamento impróprio e imoral. A partir desta constatação, analisam as discussões em torno de seus tratamentos e medidas profiláticas. João Pacheco de Souza e Roberta Barros Meira em A Armação Baleeira de Garopaba: sua justa dimensão, oferecem um estudo do sistema organizado de caça da baleia, produção e distribuição de óleo que desempenhou um papel ativo no processo de formação do município de Garopaba. Os autores tecem argumentos acerca da importância econômica da produção do óleo da baleia, e enfatizam o seu papel primordial ao imprimir um ritmo próprio à economia de algumas regiões coloniais. Em Mulheres, PCB e Feminismos: Disputas e tensões (1930-1937), Iracélli da Cruz Alves analisa a militância feminista de mulheres do Partido Comunista do Brasil entre 1930 e 1937, bem como as relações estabelecidas com outros grupos feministas do período. A preocupação central da autora é evidenciar a forma como as pecebistas concebiam a luta e as críticas que fizeram a outros 
grupos feministas. Em outro trabalho sobre as mulheres na política nacional, intitulado Ditadura Militar brasileira e memórias femininas, Príscila Paula de Sousa estuda as memórias de algumas mulheres que estiveram no cárcere durante a Ditadura Militar no Brasil, por meio de seus relatos em entrevistas e depoimentos, afim de entender quais foram as formas por elas encontradas para resistir ao que viveram no período, não se deixando paralisar pelo terror imposto pelos aparatos repressivos. No artigo que encerra este número da Esboços, Cenas brasileiras, violências, subjetividades, Mériti de Souza problematiza as repercussões dos ideais sociais que retratam o povo brasileiro como pacífico e avesso a movimentos marcados por ações violentas. De forma específica, interessa a autora neste trabalho problematizar as repercussões desses ideais sobre a organização social nacional e a constituição subjetiva do brasileiro. Finalmente, na seção de resenhas, Joelson Lopes Maciel analisa a obra Caio Prado Júnior: uma biografia política, de Luiz Bernardo Pericás.

Estar à frente de um periódico científico no Brasil não é tarefa simples face, especialmente, à escassez de recursos, que dificulta o apoio técnico especializado e coloca diversos entraves para o cumprimento de prazos e comunicação com os autores e autoras. Ainda assim, nos quatro últimos anos em que fomos editores desta revista, o apoio dos já doutores Tiago João José Alves e Diego Pacheco foi inestimável. Nos momentos mais difíceis também reconhecemos o apoio do Programa de Pós-Graduação em História, sempre atento aos desafios que enfrentamos. Agora é chegado o momento de agradecer a todos os colaboradores e colaboradoras que nos acompanharam nesses anos e nos despedirmos. A Esboços muda para melhor, e passa a se chamar Esboços: Histórias em Contextos Globais, com energia renovada, uma ampliação de seus olhares e novos editores. Nossas boas vindas aos colegas que conduzirão a revista nos próximos anos e boa leitura a todos e a todas!

\author{
Alexandre Busko Valim \\ Marcio Roberto Voigt
}

